\title{
Performance of chironja (clone 2-4) on five rootstocks after eight years of growth in two zones of Puerto Rico ${ }^{1,2}$
}

\author{
Félix M. Román-Pérez ${ }^{3}$, Agenol González-Vélez ${ }^{3}$, \\ Onilda Santana ${ }^{4}$ and Rita Rodriguez ${ }^{5}$
}

J. Agric. Univ. P.R. 93(3-4):187-193 (2009)

\begin{abstract}
The chironja (clone 2-4) was evaluated during eight years of growth at Isabela and Corozal, Puerto Rico, in the coastal and central areas, respectively. The trees were grafted on the roostocks 'Swingle citrumelo' (Citrus paradise), 'Naronja' (Citrus paradisi $\times$ Citrus aurantium), 'Cleopatra', and 'Sun Chu Sha' mandarins (Citrus reticulata), and on the hybrid HRS 812 (Sunki mandarin $\times$ Beneck trifoliate orange). The trees of the Swingle-chironja combination died at both localities during the first year because of scion-rootstock incompatibility. The rootstock HRS 812 was one of the highest yielders, even though it was infected with severe strains of the Citrus Tristeza Virus (CTV) at both sites. Although the fruits on this rootstock were small, the amount of juice was significantly greater than that of the other rootstocks at both localities. Eight years after planting, the Naronja trees were affected by CTV; $38 \%$ of the trees were lost at Isabela, and $25 \%$ at Corozal. Nevertheless, trees on this rootstock were vigorous and good yielders, producing fruits of good size and moderate fruit quality. The high incidence of CTV and Phytophthoraspp. was a limiting factor for the rootstocks susceptible to these diseases; thus there was a high mortality.
\end{abstract}

Key words: rootstocks, scion, Citrus Tristeza Virus, Phytophthora

\section{RESUMEN}

Desempeño de la chironja (clon 2-4) injertada en cinco patrones luego de ocho años creciendo en dos zonas en Puerto Rico

El clon 2-4 de chironja (Citrus sinensis $\times$ Citrus paradisiaca) fue evaluado durante los primeros ocho años de crecimiento en las localidades de Isabela y Corozal, Puerto Rico. Los árboles se injertaron en los patrones 'Swingle citrumelo' (Citrus paradisi x Poncirus trifoliata), 'Naronja' (Citrus paradisi $\times$ Citrus aurantium ), en las mandarinas 'Cleopatra' y 'Sun Chu Sha' (Citrus reticulata), y en el híbrido HRS 812 (Sunki $\times$ Beneck trifoliate orange). En am-

${ }^{1}$ Manuscript re-submitted to the Editorial Board 6 February 2008.

${ }^{2}$ The authors thank Dr. Raúl Macchiavelli, Department of Crops and Agroenvironmental Sciences, University of Puerto Rico, Mayagüez Campus, for the statistical assistance.

${ }^{3}$ Professor, Department of Crops and Agroenvironmental Sciences, Agricultural Experiment Station, College of Agricultural Science, University of Puerto Rico, Mayagüez Campus.

${ }^{4}$ Research Associate, Department of Crops and Agroenvironmental Sciences.

${ }^{5}$ Researcher (retired), Department of Crop Protection. 


\begin{abstract}
bas localidades, los árboles en la combinación Swingle-chironja murieron durante el primer año de injertados, posiblemente por incompatibilidad de injerto patrón. El patrón HRS 812 resultó ser uno de los mejores productores, aún cuando estuvo infectado con la cepa severa del virus de la tristeza de los cítricos (VTC) en ambas localidades. Aunque las frutas en este patrón fueron de tamaño pequeño, la cantidad de jugo que produjo fue significativamente superior a la de los demás patrones. Los árboles de Chironja injertados sobre Naronja fueron afectados por el VTC; un $38 \%$ murieron en Isabela y $25 \%$ en Corozal. Sin embargo, los árboles en este patrón crecieron vigorosos y resultaron buenos productores con frutas de buen tamaño y calidad moderada. La alta incidencia de VTC y Phytophthoraspp. fue un factor limitante para los patrones susceptibles a estas enfermedades, por lo que hubo una alta mortandad de los árboles.
\end{abstract}

Palabras clave: Patrones, injerto, virus tristeza cítricos, Phytophthora

\title{
INTRODUCTION
}

The chironja is a citrus fruit described for the first time in 1956 in the central zone of Puerto Rico (Moscoso, 1976). It is a citrus with characteristics similar to those of the orange Citrus sinensis [L.] Osb. and grapefruit Citrus paradisi Macf. The name "chironja", given by Carlos G. Moscoso (at the time a recognized horticulturist from the Agricultural Experiment Station), is a combination of the Puerto Rican name for orange (china) and grapefruit (toronja). It is usually larger than the average orange. It must be consumed as fresh fruit; the squeezed juice must be consumed immediately because of oxidation of several compounds present in the juice during storage. The trees come early in fruit production (September to November), but there is some production in other months of the year. Although chironja trees are vigorous and good yielders, they are susceptible to several diseases caused by fungi ( $P h y$ tophthora spp.), virus (citrus tristeza virus, psorosis) and viroids (exocortis, cachexia). The use of citrus rootstocks has been one of the most important preventive control methods of diseases such as Phytophthora root rot and citrus viroids that affect this citrus (Castle et al., 1993). The objective of this study was to evaluate the horticultural traits of the chironja (clon 2-4) in different scion-rootstock combinations.

\section{MATERIALS AND METHODS}

The chironja (clone 2-4) was evaluated during eight years of growth at the Isabela and Corozal Substations, located in Puerto Rico's northern coastal and central regions, respectively. In 1992, scions of clone 24 were grafted on the roostocks Swingle citrumelo, Naronja, Cleopatra mandarin, Sun Chu Sha mandarin, and the hybrid HRS 812 (Sunki × Beneck trifoliate orange). At Isabela the trees were planted in a soil of the Coto series (very fine, kaolinitic, isohyperthermic Typic Hapludox) 
(Beinroth et al., 2003) with $\mathrm{pH}$ of 5.9 and with good drainage. At Corozal the soil was a Corozal series (very-fine, mixed, semiactive, isohypertermic Aquic Hapludults) with $\mathrm{pH}$ of 6.5 (after applications of $\mathrm{CaCO}_{3}$ ) and with poor drainage. A randomized complete block design with four replications (two trees per plot) was used. Trees were planted at a distance of $5.9 \mathrm{~m} \times 5.3 \mathrm{~m}$. The measured variables were mean number of fruit per tree, fruit weight, percentage of juice (calculated by extraction of juice from the fruit), total soluble solids (TSS) (measured with a refractrometer in degrees brix), acidity (calculated by titration), TSS:Acid ratio, $\mathrm{pH}$, canopy volume (estimated by using the formula $0.524 \times$ square diameter $\times$ height) (Turrell, 1961), and the efficiency (number of fruits per cubic meter of canopy volume). Fruit quality (total soluble solids, acidity, TSS:Acid ratio, and $\mathrm{pH}$ ) was calculated as the mean of these variables from harvests in 1999 and 2000. At the end of the experiment, observations were made for symptoms of diseases such as citrus tristeza virus (CTV), foot and root rot (Phytophthora), exocortis viroid, and psorosis virus. Bark injuries and gummosis on the trunk or roots near the ground level were the symptoms used to identify the diseases and to determine the percentage of trees affected (Roistacher, 1991). The Enzyme-Linked ImmunoSorbent Assay (ELISA) test with the universal antibody G604 was used to detect whether the trees were infected with CTV. The monoclonal antibody MCA13 was used for the detection of severe strains of CTV.

\section{RESULTS AND DISCUSSION}

As recorded in preliminary data published by Bowman and Román (1999), all trees of Swingle rootstock died at an early stage (year one) of development because of scion-rootstock incompatibility (Table 1). The 1998 harvest was lost because of hurricane Georges, also probably affecting the 1999 harvest in terms of number of fruits per tree. The hurricane may have had some effect on the behavior of the trees in subsequent years, since the root system may have suffered because of the effect of the winds and high humidity of the soil.

Eight years after planting establishment, the Naronja trees were affected by CTV; $38 \%$ were lost at Isabela, $25 \%$ at Corozal. Nevertheless, trees on Naronja rootstock were vigorous and good yielders, producing fruits of good size and moderate quality. The high incidence of CTV and of Phytophthora spp. as a limiting factor for the rootstocks susceptible to these diseases resulted in a high percentage of mortality of the trees (Table 1). Eight years after the trees were planted there was a high percentage of visible symptoms of Phytophthora, especially at Isabela (Table 1). All of the trees on the rootstock HRS 812 were in- 
TABLE 1.-Mortality and disease due to Phytophthora or Citrus Tristeza Virus (CTV) symptoms after eight years of growth of chironja grafted onto various rootstocks.

\begin{tabular}{|c|c|c|c|c|c|}
\hline \multirow[b]{2}{*}{ Rootstock } & \multicolumn{2}{|c|}{$\begin{array}{c}\text { Diseased trees } \\
(\%)\end{array}$} & \multicolumn{2}{|c|}{ Mortality $(\%)$} & \multirow[b]{2}{*}{ Observations } \\
\hline & Isabela & Corozal & Isabela & Corozal & \\
\hline Swingle citrumelo & - & - & - & - & $\begin{array}{l}\text { Trees died because of scion- } \\
\text { rootstock incompatibility }\end{array}$ \\
\hline HRS 812 & 63 & 57 & 0 & 0 & Death due to Phytophthora \\
\hline Cleopatra mandarin & 75 & 33 & 50 & 25 & Death due to Phytophthora \\
\hline Sun Chu Sha mandarin & 83 & 14 & 25 & 13 & Death due to Phytophthora \\
\hline Naronja & 80 & 17 & 38 & 25 & $\begin{array}{l}\text { Death due to Phytophthora } \\
\text { or to CTV }\end{array}$ \\
\hline
\end{tabular}

fected with a severe strain of CTV; however, no symptoms of the disease were detected. Therefore, from the standpoint of resistance to CTV, HRS 812 rootstock would be appropriate for both of the locations studied. At Isabela the trees on this rootstock performed as well as those on Naronja in regard to the cumulative yield, producing fruits of good quality (Table 2). At Corozal, HRS 812 cumulative yield was significantly superior (1,024 fruits per tree) to that of Sun Chu Sha and to that of Naronja ( 744.6 and 739.2 fruits, respectively). Table 3 shows the mean canopy volume and efficiency of the chironja trees at the two localities. At Isabela, only the canopy volume of Naronja rootstock significantly exceeded that of HRS 812 . However, there were no significant differences in efficiency among the rootstocks. At Corozal, there were no significant differences in canopy volume among the rootstocks (Table 3). The efficiency of rootstocks HRS 812 and Cleopatra mandarin significantly exceeded that of Naronja.

TABLE 2.-Mean number of fruits per tree on five rootstocks at Isabela and Corozal.

\begin{tabular}{lccccc}
\hline & \multicolumn{2}{c}{ Isabela } & & \multicolumn{2}{c}{ Corozal } \\
\cline { 2 - 3 } \cline { 5 - 6 } Rootstocks & $1996-2000^{1}$ & 2000 & & $1996-2000$ & 2000 \\
\hline Swingle citrumelo & - & - & - & - & - \\
HRS 812 & $891.9 \mathrm{a}$ & $224.8 \mathrm{ab}^{2}$ & & $1,024.0 \mathrm{a}$ & $330.8 \mathrm{a}$ \\
Cleopatra mandarin & $497.2 \mathrm{~b}$ & $222.9 \mathrm{ab}$ & & $861.8 \mathrm{ab}$ & $309.5 \mathrm{a}$ \\
Sun Chu Sha mandarin & $368.8 \mathrm{~b}$ & $130.7 \mathrm{~b}$ & & $744.6 \mathrm{~b}$ & $268.3 \mathrm{a}$ \\
Naronja & $725.8 \mathrm{a}$ & $304.4 \mathrm{a}$ & & $739.2 \mathrm{~b}$ & $150.8 \mathrm{~b}$ \\
LSD $\leq(0.05)$ & 211.7 & 166.1 & & 262.8 & 84.6 \\
\hline
\end{tabular}

${ }^{1}$ Cumulative average over the years 1996 to 2000, except for 1998.

${ }^{2}$ Within a column, values followed by the same letter are not significantly different. 
TABLE 3.-Mean canopy volume and efficiency (number of fruits per canopy volume) of chironja on five rootstocks at Isabela and Corozal measured in year 2000.

\begin{tabular}{lccccc}
\hline & \multicolumn{2}{c}{ Isabela } & & \multicolumn{2}{c}{ Corozal } \\
\cline { 2 - 3 } \cline { 5 - 6 } Rootstocks & $\begin{array}{c}\text { Canopy vol. } \\
\left(\mathrm{m}^{3}\right)\end{array}$ & $\begin{array}{c}\text { Efficiency } \\
\left.\text { (fruits } / \mathrm{m}^{3} \text { can. vol. }\right)\end{array}$ & $\begin{array}{c}\text { Canopy vol. } \\
\left(\mathrm{m}^{3}\right)\end{array}$ & $\begin{array}{c}\text { Efficiency } \\
\left(\text { fruits } / \mathrm{m}^{3} \text { can. vol.) }\right.\end{array}$ \\
\hline Swingle citrumelo & - & - & - & - \\
HRS 812 & $5.38 \mathrm{~b}^{2}$ & $40.6 \mathrm{a}$ & & $4.40 \mathrm{a}$ & $75.0 \mathrm{a}$ \\
Cleopatra mandarin & $5.80 \mathrm{ab}$ & $39.0 \mathrm{a}$ & & $4.55 \mathrm{a}$ & $72.7 \mathrm{a}$ \\
Sun Chu Sha mandarin & $5.63 \mathrm{ab}$ & $23.4 \mathrm{a}$ & & $4.92 \mathrm{a}$ & $54.8 \mathrm{ab}$ \\
Naronja & $6.15 \mathrm{a}$ & $46.5 \mathrm{a}$ & & $4.45 \mathrm{a}$ & $35.3 \mathrm{~b}$ \\
LSD $\leq(0.05)$ & 0.63 & $\mathrm{~ns}$ & $\mathrm{~ns}$ & 31.32 \\
\hline
\end{tabular}

${ }^{1}$ Number of fruits per cubic meter of canopy volume.

${ }^{2}$ Within a column, values followed by the same letter are not significantly different.

At Isabela, fruit weight of HRS 812 was significantly lower than that of the other rootstocks (Table 4). At Corozal both HRS 812 and Sun Chu Sha produced smaller fruits than Naronja. At Isabela the juice percentage of rootstock HRS 812 was significantly superior to that of the other rootstocks, whereas at Corozal, juice percentage of Naronja was significantly lower than that of the other rootstocks. At both sites, the highest total soluble solids (TSS, ${ }^{\circ}$ Brix) were obtained with the HRS 812 rootstock (Table 5). At Corozal, Naronja was not significantly different from this rootstock. There were no significant differences in TSS between Cleopatra and Sun Shu Cha mandarins, two similar rootstock varieties both in horticultural traits as well as in the quality of the fruits. For fruit acidity at Isabela there was no significant difference among the rootstocks. At Corozal the acidity of Sun Chu Sha was significantly lower than that of HRS 812 and of Naronja. The highest TSS:TA ratio at Corozal was shown by Sun Chu Sha and was signifi-

TABLE 4.-Fruit weight (g) and percentage of juice from chironja on five rootstocks at Isabela and Corozal, 1999 and 2000.

\begin{tabular}{lccccc}
\hline & Isabela & Corozal & & Isabela & Corozal \\
\cline { 2 - 3 } \cline { 5 - 6 } Rootstocks & Fruit weight $(\mathrm{g})$ & Fruit weight $(\mathrm{g})$ & & \% juice & \% juice \\
\hline Swingle citrumelo & - & - & & - & - \\
HRS 812 & $419.3 \mathrm{~b}^{\mathbf{1}}$ & $378.0 \mathrm{~b}$ & & $49.0 \mathrm{a}$ & $40.3 \mathrm{a}$ \\
Cleopatra mandarin & $492.1 \mathrm{a}$ & $390.0 \mathrm{ab}$ & & $35.9 \mathrm{~b}$ & $39.3 \mathrm{a}$ \\
Sun Chu Sha mandarin & $504.6 \mathrm{a}$ & $377.4 \mathrm{~b}$ & & $41.6 \mathrm{~b}$ & $39.9 \mathrm{a}$ \\
Naronja & $546.8 \mathrm{a}$ & $419.4 \mathrm{a}$ & & $37.6 \mathrm{~b}$ & $35.3 \mathrm{~b}$ \\
LSD $\leq(0.05)$ & 72.7 & 38.4 & & 6.4 & 2.1 \\
\hline
\end{tabular}

${ }^{1}$ Within a column, values followed by the same letter are not significantly different. 
TABLE 5.-Fruit Total Solid Solubles (TSS), Acidity (TA), TSS / TA ratio and pH from chironja on five rootstocks at Isabela and Corozal, mean from 1999 and 2000.

\begin{tabular}{|c|c|c|c|c|c|c|c|c|}
\hline \multirow[b]{3}{*}{ Rootstocks } & \multicolumn{4}{|c|}{ Isabela } & \multicolumn{4}{|c|}{ Corozal } \\
\hline & & & TSS/TA & & & & TSS/TA & \\
\hline & TSS & Acidity & ratio & $\mathrm{pH}$ & TSS & Acidity & ratio & $\mathrm{pH}$ \\
\hline Swingle citrumelo & - & - & - & - & - & - & - & - \\
\hline HRS 812 & $10.5 \mathrm{a}$ & $0.46 \mathrm{a}$ & $22.8 \mathrm{a}$ & $4.3 \mathrm{a}$ & $9.9 \mathrm{a}^{1}$ & $0.48 \mathrm{a}$ & $20.7 \mathrm{ab}$ & $4.0 \mathrm{a}$ \\
\hline Cleopatra mandarin & $8.9 \mathrm{bc}$ & $0.45 \mathrm{a}$ & $20.3 \mathrm{ab}$ & $4.2 \mathrm{a}$ & $9.4 \mathrm{~b}$ & $0.44 \mathrm{ab}$ & $21.6 \mathrm{ab}$ & $3.9 \mathrm{a}$ \\
\hline Sun Chu Sha mandarin & $9.3 \mathrm{~b}$ & $0.46 \mathrm{a}$ & $19.4 \mathrm{~b}$ & $4.0 \mathrm{~b}$ & $9.3 \mathrm{~b}$ & $0.40 \mathrm{~b}$ & $23.4 \mathrm{a}$ & $3.9 \mathrm{a}$ \\
\hline Naronja & $8.5 \mathrm{c}$ & $0.43 \mathrm{a}$ & $22.2 \mathrm{a}$ & $4.0 \mathrm{~b}$ & $9.6 \mathrm{ab}$ & $0.48 \mathrm{a}$ & $20.3 \mathrm{~b}$ & $3.9 \mathrm{a}$ \\
\hline DMS $\leq(0.05)$ & 0.56 & 0.06 & 2.67 & 0.12 & 0.36 & 0.07 & 3.08 & 0.29 \\
\hline
\end{tabular}

${ }^{1}$ Within a column, values followed by the same letter are not significantly different.

cantly higher than that of Naronja. At Isabela the TSS:TA ratio of Sun Chu Sha was significantly lower than that of HRS 812 and Naronja. There was no significant difference among the rootstocks at Corozal for $\mathrm{pH}$; in Isabela HRS 812 and Cleopatra had the highest $\mathrm{pH}$.

Pérez and Bosque-Lugo (1972) reported on Chironja in three rootstocks at Adjuntas and Isabela; they found different responses among cultivars with regard to the quality of the fruit. Our study shows that the rootstock and the ecological zone affect the behavior of the cultivar. Pérez et al. (1980) also reported low acid levels in chironja fruit, levels similar to those obtained in this study. This finding suggests that low acid level is a characteristic of this fruit that is not influenced by the above mentioned factors.

Chironja and Swingle rootstocks were incompatible; thus there was $100 \%$ tree mortality. The rootstocks Cleopatra, Sun Chu Sha, and Naronja were susceptible to Phytophthora; the susceptibility of Naronja to CTV was confirmed. Therefore, Naronja should not be used in Puerto Rico. The rootstock HRS 812 was one of the best yielders, even though it was infected with severe strains of CTV at both sites. Although the fruits on this rootstock were small, the percentages of juice and total soluble solids were acceptable at the two sites. Another advantage of this rootstock is its great capacity for survival under adverse soil and climate conditions, all of which will result in orchards with long productive lives.

\section{LITERATURE CITED}

Beinroth, F. H., E. J. Robert, J. L. Lugo, C. L. Santiago, S. Ríos and G. R. Brannon, 2003. Updated Taxonomic Classification of the Soils of Puerto Rico, 2002. University of Puerto Rico, Mayagüez Campus, College of Agricultural Science, Agricultural Experiment Station, Bulletin $303.73 \mathrm{pp}$. 
Bowman, D. K. and F. M. Román, 1999. New rootstocks for orange and mandarin. Proceedings of the Caribbean Food Crops Society 35:119-130.

Castle, W. S., D. P. H. Tucker, A. H. Kresdorn and C. O. Youtsey, 1993. Rootstocks for Florida Citrus: Rootstocks Selection, the first step to success. 2nd ed. University of Florida, IFAS. 92 pp.

Moscoso, C. G., 1976. La chironja: Una nueva fruta cítrica puertorriqueña. University Puerto Rico-Mayagüez, Agricultural Experiment Station. Bull. 248.

Pérez, A. and R. Bosque Lugo, 1972. Effect of the rootstock on certain fruit characteristics. J. Agric. Univ. P.R. 51(3):301-306.

Pérez, A., C. J. Torres and J. Green, 1980. Behavior of ten chironja clones at three sites. II. Fruit Quality 54 (3):323-329.

Roistacher, C. N., 1991. Graft Transmisible Diseases of Citrus. Handbook for Detection and Diagnosis. International Organization of Citrus Virologists, FAO, Rome, 1991.

Turrell, F. M., 1961. Growth of the photosynthetic area of citrus. Botanical Gazette 122 (4): 284-298. 